Works of the Faculty of Forestry

University of Sarajevo

No. 2, 2018 (33-40)

UDK 631.547.1:582.665.11]:630*232(560)

631.547.1: 582.746.46]:630*232(560)

\title{
DETERMINATION OF GERMINATION CHARACTERISTICS OF Calligonum polygonoides AND Koelreuteria paniculata SEEDS
}

\section{Utvrđivanje karakteristika klijavosti sjemena vrsta Calligonum polygonoides $i$ Koelreuteria paniculata}

\author{
Fahrettin Atar $^{1}$, Ali Bayraktar ${ }^{1}$, Nebahat Yildirim $^{1}$, İbrahim Turna ${ }^{1}$
}

\begin{abstract}
The success of the afforestation works (ecological and biological compatibility, economic success, etc.) depends on the use of seeds of known origin or quality seedlings. For this reason, it is important to determine seed characteristics and to eliminate dormancy. In this study, it was aimed to determine the germination characteristics of seeds of Calligonum polygonoides L. collected from Iğdır and Koelreuteria paniculata Laxm. obtained from Trabzon. In order to eliminate the dormancy for Calligonum polygonoides, 11 different pretreatments including control, cold water (1-2 days), hot water (10-15 min), gibberellic acid ( $\mathrm{GA}_{3} 1000 \mathrm{ppm}, \mathrm{GA}_{3} 3000$ ppm), sulfuric acid $\left(\mathrm{H}_{2} \mathrm{SO}_{4}, 5-10 \mathrm{~min}\right), 5 \mathrm{~min}$ with $\mathrm{H}_{2} \mathrm{SO}_{4}+20 \mathrm{~min}$ with $\mathrm{GA}_{3} 1000 \mathrm{ppm}$ and 10 min with $\mathrm{H}_{2} \mathrm{SO}_{4}+20 \mathrm{~min}$ with $\mathrm{GA}_{3} 3000 \mathrm{ppm}$ were applied. The highest germination percentage was obtained as $50 \%$ in sulfuric acid ( 5 min) pretreatment, while the lowest germination percentage was obtained as $3.33 \%$ in control pretreatment. In hot water pretreatments, germination didn't occur. In order to eliminate the dormancy for Koelreuteria paniculata, pretreatments including control, cold water (1 day), hot water (10 min), GA 1000 ppm, GA 3000 ppm, $\mathrm{H}_{2} \mathrm{SO}_{4} 5-10 \mathrm{~min}, 5$ min with $\mathrm{H}_{2} \mathrm{SO}_{4}+$ 20 min with $\mathrm{GA}_{3} 1000 \mathrm{ppm}$ and 10 min with $\mathrm{H}_{2} \mathrm{SO}_{4}+20$ min with $\mathrm{GA}_{3} 3000$ ppm were applied. While the lowest germination percentage occurred as $73.33 \%$ in $\mathrm{H}_{2} \mathrm{SO}_{4}(10$ min) pretreatment, the highest germination percentage took place as $93.33 \%$ in 10 min with $\mathrm{H}_{2} \mathrm{SO}_{4}+20$ min with $\mathrm{GA}_{3} 3000$ ppm and cold water (1 day) pretreatments.
\end{abstract}

Key words: Calligonum polygonoides, Koelreuteria paniculata, seed, dormancy, pretreatment.

\section{INTRODUCTION - Uvod}

Seed germination and seedling establishment are the most crucial periods in the plant life cycle (MAYER and POLJAKOFF-MAYBER, 1989). Germination starts with water uptake by seeds and terminates with the initial elongation of the embryonic axis (BEWLEY, 1997). Completion of germination can be seen by the emergence of the radicle (OGAWA et al., 2003). On the other hand, seed dormancy is a physiological condition in which the seeds cannot germinate even under the most suitable germination conditions or do not exhibit uniform germination. Seed germination is generally hampered by external factors (oxygen, temperature, humidity and light) and internal 
factors (e.g. seed coat, endosperm embryo) (BEWLEY and BLACK, 1982; BRADBEER, 1988; COPELAND and MCDONALD, 2001; KOORNNEEF, et al., 2002; BASKIN and BASKIN, 2004; BLACK et al., 2008).

Goldenrain-tree (Koelreuteria paniculata Laxm.) spread as native species in China and well established in Korea. It is a woody perennial, mainly used for landscape purposes due to its beautiful yellow flowers and green leaves. It is wide spread as an ornamental tree but the propagation is difficult because of apparent seed dormancy (PARK and REHMAN, 1999; REHMAN and PARK, 2001). Seed coat, embryo or the combination of the two can be reason the dormancy; this is why the seeds need to be well prepared before sowing (PARK and REHMAN, 1999; SABINA, 2009; SABINA and CORNELIA, 2011; REHMAN and PARK, 2000a).

Calligonum polygonoides L. (Polygonaceae) is a dominant perennial shrub in active sand dunes and stabilized sand fields (MAO and PAN, 1986; TAO, 2000). The species can persist in mobile sandy dunes under extreme drought conditions (LIU, 19851990). It is known for high tolerance to water deficiency in the Tunisian Saharian regions and appears to be appropriate for revegetation of desert (MAO et al., 1983; MAO and PAN, 1986; ZHANG, 1992; TAO, 2000). This shrub has great potentialities to provide different products and services as forage, traditional medicine, halting desert encroachment and stabilizing sand dune (LIU, 1985-1990; TAO, 2000). Seed coat hardness and impermeability to water may be the most important causes of Calligonum spp. dormancy (YU and WANG, 1998; TAO et al. 2000; REN and TAO, 2004).

Unfortunately, there is limited information concerning the potential seed dormancy problems of Koelreuteria paniculata and Calligonum polygonoides. For this reason, the objective of the present study was to devise an effective method for breaking dormancy of Koelreuteria paniculata and Calligonum polygonoides seeds.

In this study, it is examined that the effects of several pretreatments on germination of Koelreuteria paniculata and Calligonum polygonoides seeds, with the goal of providing practical suggestions for breaking dormancy.

\section{MATERIALS AND METHODS - Materijal i metode}

It was aimed to determine the germination characteristics of seeds of Calligonum polygonoides L. collected from Iğdır and Koelreuteria paniculata Laxm. obtained from Trabzon. After the collection of seeds, empty and rotten seeds were removed. Koelreuteria paniculata seeds were manually scarified by piercing seeds with a needle at the cotyledon end. Seeds were allowed to air-dry and stored at ambient temperature $\left(25^{\circ} \mathrm{C}\right)$. Germination experiments were conducted at $25 \pm 2{ }^{\circ} \mathrm{C}$ temperature and $70 \pm 2 \%$ humidity level at the Research and Application Greenhouse. Peat+soil+perlite determined by 7:2:1 ratio was used as germination medium. Line sowing method was used in the sowing of the seeds and sowing was conducted based on the randomized complete block design. In the prepared crates, lines were opened to the depth of 2-3 times of the thickness of the seed with the line opening bar. Seeds were sowed with $3 \times 10$ sampling in October. Each treatment was replicated three times and 
10 seeds were used in each replicate. In total, it was used 270 seeds for Koelreuteria paniculata and 330 seeds for Calligonum polygonoides in the scope of this study. In order to eliminate the dormancy for Calligonum polygonoides, 11 different pretreatments including control, cold water (1-2 days), hot water (10-15 min), gibberellic acid $\left(\mathrm{GA}_{3} 1000 \mathrm{ppm}, \mathrm{GA}_{3} 3000 \mathrm{ppm}\right)$, sulfuric acid $\left(\mathrm{H}_{2} \mathrm{SO}_{4}, 5-10 \mathrm{~min}\right), 5$ min with $\mathrm{H}_{2} \mathrm{SO}_{4}+20$ min with $\mathrm{GA}_{3} 1000$ ppm and 10 min with $\mathrm{H}_{2} \mathrm{SO}_{4}+20$ min with $\mathrm{GA}_{3} 3000 \mathrm{ppm}$ were applied. Koelreuteria paniculata, 9 different pretreatments including control, cold water (1 day), hot water (10 min), GA 1000 ppm, GA 3000 ppm, $\mathrm{H}_{2} \mathrm{SO}_{4}$ 5-10 min, 5 min with $\mathrm{H}_{2} \mathrm{SO}_{4}+20$ min with $\mathrm{GA}_{3} 1000$ ppm and 10 min with $\mathrm{H}_{2} \mathrm{SO}_{4}+20$ min with $\mathrm{GA}_{3} 3000$ ppm. Germination status was recorded every day. Seedling emergence (cotyledons visible at the media surface) was expressed as the percentage of viable seeds.

Germination data related to this study were analyzed using the SPSS 23 statistical program.

\section{RESULTS - Rezultati}

As a result of the study, the results of variance analysis and the germination percentage related to applied pretreatments for removing of dormancy in seeds of Calligonum polygonoides and Koelreuteria paniculata are given in Table 1.

Table 1. The results of germination percentages related to pretreatments

Tabela 1. Rezultati procenta ostvarene klijavosti u odnosu na tretmane

\begin{tabular}{|c|c|c|c|c|}
\hline Species & Treatments & $\begin{array}{l}\text { Germination } \\
\text { Percentage }(\%)\end{array}$ & $\mathbf{F}$ & $\mathbf{P}$ \\
\hline \multirow{9}{*}{ 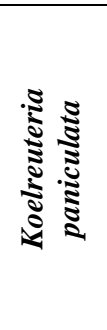 } & 1-Control & 76.67 & \multirow{9}{*}{164.769} & \multirow{9}{*}{$0.000^{*}$} \\
\hline & 2-Cold water ( 1 day) & 93.33 & & \\
\hline & 3-Hot water (10 min) & 86.67 & & \\
\hline & $4-\mathrm{GA}_{3} 1000 \mathrm{ppm}(30 \mathrm{~min})$ & 83.33 & & \\
\hline & $5-\mathrm{GA}_{3} 3000 \mathrm{ppm}(30 \mathrm{~min})$ & 83.33 & & \\
\hline & $6-\mathrm{H}_{2} \mathrm{SO}_{4} 5 \mathrm{~min}$ & 76.67 & & \\
\hline & $7-\mathrm{H}_{2} \mathrm{SO}_{4} 10 \mathrm{~min}$ & 73.33 & & \\
\hline & $8-\mathrm{H}_{2} \mathrm{SO}_{4} 5 \mathrm{~min}+\mathrm{GA}_{3} 1000 \mathrm{ppm}(20 \mathrm{~min})$ & 90.00 & & \\
\hline & $9-\mathrm{H}_{2} \mathrm{SO}_{4} 10 \mathrm{~min}+\mathrm{GA}_{3} 3000 \mathrm{ppm}(20 \mathrm{~min})$ & 93.33 & & \\
\hline \multirow{11}{*}{ 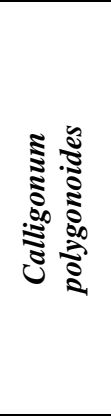 } & 1-Control & 3.33 & \multirow{11}{*}{1238.657} & \multirow{11}{*}{$0.000^{*}$} \\
\hline & 2-Cold water (1 day) & 36.67 & & \\
\hline & 3-Cold water (2 day) & $40, .0$ & & \\
\hline & 4-Hot water (10 min) & 0.00 & & \\
\hline & 5-Hot water (15 min) & 0.00 & & \\
\hline & 6-GA $1000 \mathrm{ppm}$ (30 min) & 26.67 & & \\
\hline & 7-GA $3000 \mathrm{ppm}(30 \mathrm{~min})$ & 33.33 & & \\
\hline & $8-\mathrm{H}_{2} \mathrm{SO}_{4}(5 \mathrm{~min})$ & 50.00 & & \\
\hline & $9-\mathrm{H}_{2} \mathrm{SO}_{4}(10 \mathrm{~min})$ & 46.67 & & \\
\hline & $10-\mathrm{H}_{2} \mathrm{SO}_{4} 5 \mathrm{~min}+\mathrm{GA}_{3} 1000 \mathrm{ppm}(20 \mathrm{~min})$ & 36.67 & & \\
\hline & $11-\mathrm{H}_{2} \mathrm{SO}_{4}(10 \mathrm{~min})+\mathrm{GA}_{3} 3000 \mathrm{ppm}(20 \mathrm{~min})$ & 20.00 & & \\
\hline
\end{tabular}

$* \mathrm{P}<0.05$ (There is a statistically significant difference.) 
As can be seen from Table 1, there were statistically significant differences $(\mathrm{P}<0.05)$ in terms of pretreatments for both species. While the lowest germination percentage in Koelreuteria paniculata seeds occurred as $73.33 \%$ in $\mathrm{H}_{2} \mathrm{SO}_{4}(10 \mathrm{~min})$ pretreatment, the highest germination percentage took place as $93.33 \%$ in $10 \mathrm{~min}$ with $\mathrm{H}_{2} \mathrm{SO}_{4}+20$ min with $\mathrm{GA}_{3} 3000$ ppm and cold water (1 day) pretreatments. For the seeds of Calligonum polygonoides, the highest germination percentage was obtained as 50\% in sulfuric acid $(5 \mathrm{~min})$ pretreatment, whereas the lowest germination percentage was obtained as $3.33 \%$ in control pretreatment. In hot water pretreatments, germination didn't occur in Calligonum polygonoides seeds.

Duncan test was performed to determine the groups that were occurred in terms of pretreatments for germination percentages (Figure 1 and Figure 2).

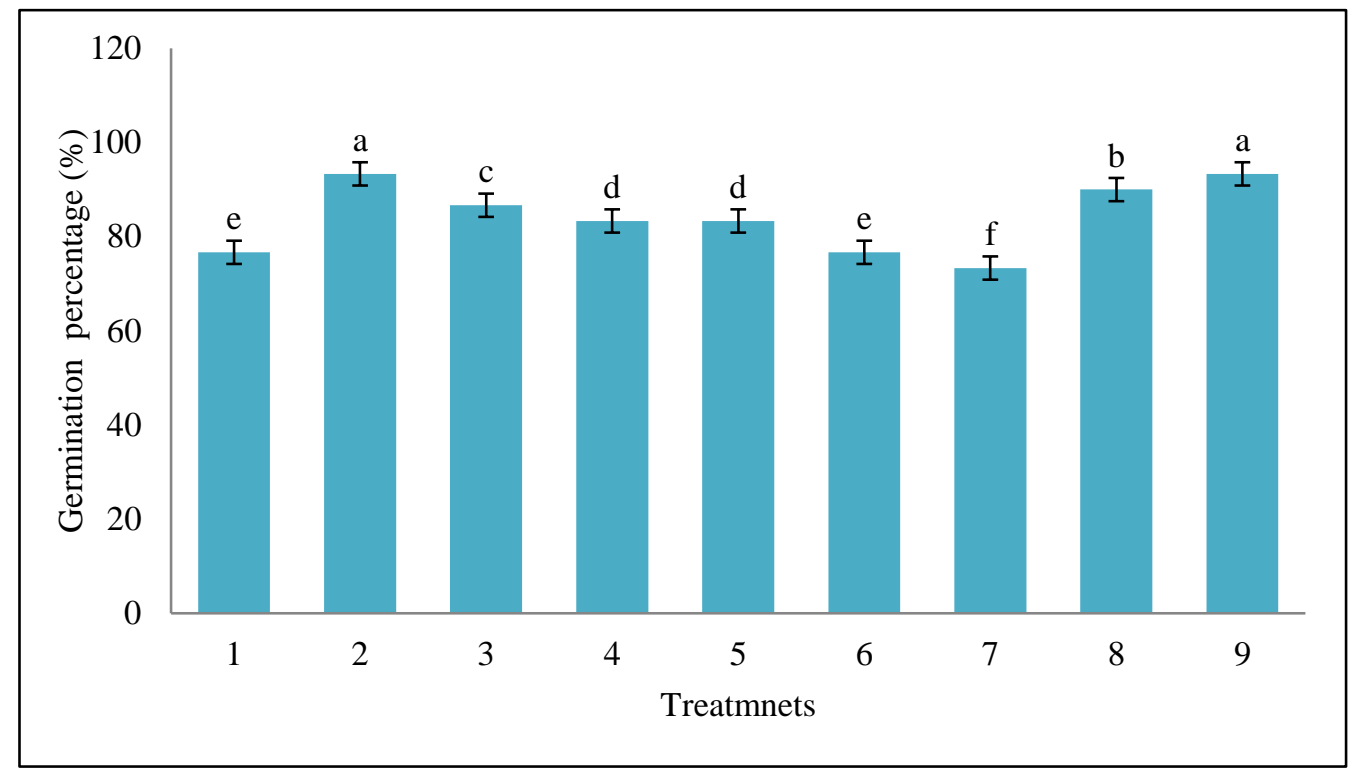

Figure 1. Duncan test results for Koelreuteria paniculata

Figure 1. Rezultati Duncan testa za Koelreuteria paniculata 


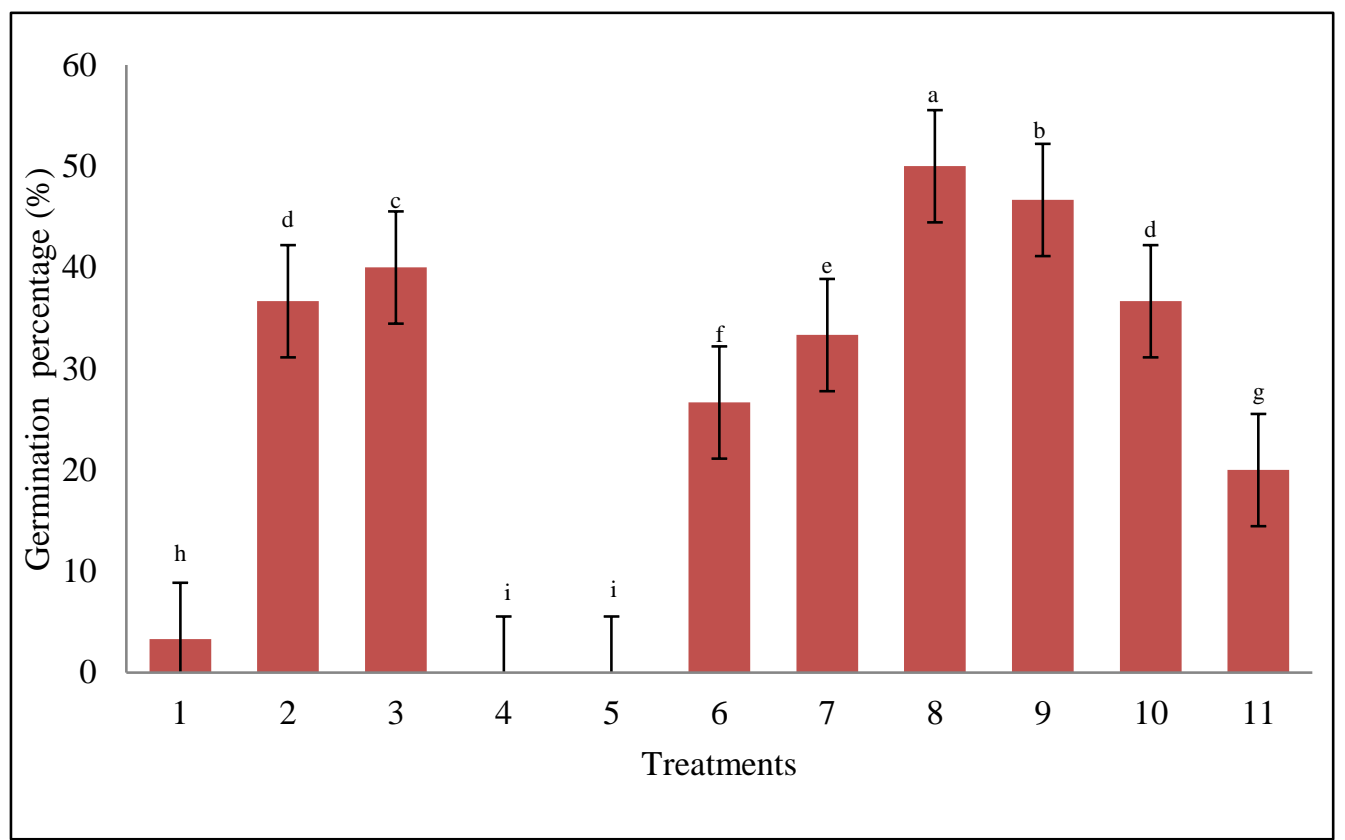

Figure 2. Duncan test results for Calligonum polygonoides

Figure 2. Rezultati Duncan testa za Calligonum polygonoides

As a result of the Duncan test, it was seen that there were 6 groups in Koelreuteria paniculata and 9 different groups in Calligonum polygonoides. For Koelreuteria paniculata, Cold water (1 day) and $\mathrm{H}_{2} \mathrm{SO}_{4} 10$ min $+\mathrm{GA}_{3} 3000$ ppm (20 $\mathrm{min}$ ) pretreatments created first group with the highest values, and $\mathrm{H}_{2} \mathrm{SO}_{4}(10 \mathrm{~min})$ took place the last group having the lowest value. For Calligonum polygonoides, first group was created by $\mathrm{H}_{2} \mathrm{SO}_{4} 5 \mathrm{~min}$ pretreatment, while the last group was formed by hot water $10 \mathrm{~min}$ and $15 \mathrm{~min}$ pretreatments.

\section{DISCUSSION - Diskusija}

REHMAN and PARK (2000a) reported that scarified seeds of goldenrain tree, without soaking or after soaking-redrying, had $44 \%$ germination after 60 days of moist chilling, which was increased to more than $50 \%$ when Seeds were soaked or soakedredried in DW or $\mathrm{GA}_{3}$ for $5 \mathrm{~h}$ and moist chilled for 60 days (DW) and 30 days $\left(\mathrm{GA}_{3}\right)$. However, germination of seeds soaked for $24 \mathrm{~h}$ and moist chilled was very low, but increased if the seeds were redried after soaking. Dry chilling after soaking or soakingredrying for $24 \mathrm{~h}$ also promoted germination and a maximum of $>50 \%$ germination was achieved after 15 days of dry chilling. In other research, exogenous application of 100 , 200 and $300 \mathrm{ppm} \mathrm{GA} 3$ increased germination of scarified seeds from 0 (control) to 17, 18 and $15 \%$, respectively. Pre-chilling in distilled water (DW) for 60 days increased germination to $44 \%$. Compared with DWchilled seeds, germination of seeds chilled for 
15 days in GA3 was significantly increased and germination of Seeds chilled in 100, 200 and 300 ppm GA3 was 60, 51 and 54\%, respectively, after 30 days (REHMAN and PARK, 2000b). The highest germination (94\%) was obtained using $100 \mathrm{~mL} / \mathrm{L}$ EM 1 application and stratification for 45 days at $4^{\circ} \mathrm{C}$. Stratification was also effective for breaking dormancy of $K$. paniculata seeds with EM 1 and 45 days or 60 days of stratification (ERTEKIN, 2011). RUDOLF, (1974), examined untreated seeds and found germination of only $2 \%$ after 29 days, whereas germination increased to $52 \%$ after acid plus stratification treatment. No unscarified seed germinated in any of the treatments, indicating that goldenrain tree seeds have hard, impermeable seed-coat dormancy. In this study, high germination (93.33\%) was obtained in 10 min with $\mathrm{H}_{2} \mathrm{SO}_{4}+20$ min with $\mathrm{GA}_{3} 3000$ ppm and cold water (1 day) pretreatments.

The germination response of Calligonum azel, $C$. arich and $C$. comosum to mechanical, physical and chemical scarifications, applied for overcoming dormancy, has been studied under controlled conditions. In all three Calligonum species, the germination of the untreated (control) seeds was relatively low, indicating the presence of coat-imposed dormancy in a fraction of the studied seeds. Chemical scarification with sulphuric acid (96\%) was effective in breaking seed dormancy and consequently in increasing the rate and the final percentage of germination (DHIEF et al., 2012). YU and WANG (1998), showed that the seed dormancy rates of the three Calligonum species are more than 95\%, and the dormant degrees are rather deep. REN and TAO (2004), studied the effects of abrasion, sulphuric acid, boiling water, cold stratification and seed exudates (water-soluble inhibitors from the testa) treatments on the germination of 10 Calligonum species. They concluded that the rate and the percentage of the germination of these species are greatly increased by mechanical or chemical scarification; however, the lowest values are obtained with the exudate treatment. According to ZHANG (1992), the most appropriate pretreatments for Calligonum species are sulfuric acid and cold stratification. In the present study, the seed germination percentage of Calligonum polygonoides was enhanced by an immersion time in sulphuric acid and increased with time until 5 min.

In conclusion, 10 min with $\mathrm{H}_{2} \mathrm{SO}_{4}+20$ min with $\mathrm{GA}_{3} 3000 \mathrm{ppm}$ and cold water (1 day) pretreatments can successfully break dormancy in goldenrain tree seeds, resulting in the easy production of seedlings. Hence, goldenrain tree is a suitable for planting in urban parks and gardens. Sulfuric acid $(5 \mathrm{~min})$, with the highest germination percentage (50\%), can be used in order to eliminate the dormancy for Calligonum polygonoides. In the context of the potential use of Calligonum species as an alternative in the arid desert regions, it can be suggested that seed germination and seedling emergence under the natural environmental conditions still deserve further research.

\section{ACKNOWLEDGEMENT}

The study was published as a summary text on abstract book of in International Symposium "People-Forest-Science", October 10-12, 2018, Sarajevo, Bosnia and Herzegovina. 


\section{REFERENCES - Literatura}

BEWLEY, J.D. (1997): Seed Germination and Dormancy. Plant Cell 9, 1055-1066.

DHIEF, A., GORAI, M., ASCHI-SMITI, S., NEFFATI, M. (2012): Effects of Some SeedCoat Dormancy Breaking Treatments on Germination of Three Calligonum species occurring in Southern desert of Tunisia. Ecol Med, 38, 19-27.

ERTEKIN, M. (2011): Effects of Microorganisms, Hormone Treatment and Stratification on Seed Germination of Goldenrain Tree (Koelreuteria paniculata). International Journal of Agriculture and Biology, 13(1).

KOORNNEEF, M., BENTSINK, L., HILHORST, H. (2002): Seed Dormancy and Germination. Curr. Opin. Plant Biol. 5, 33-36.

LIU, Y.X. (1985-1990): Flora in Desertis Reipublicae Populorum Sinarum, I-III. Science Press, Beijing.

MAYER, A. M., POLIJAKOFF-MAYBER, A. (1989): The Germination of Seeds, 4th ed. Pergamon Press, London, $270 \mathrm{p}$.

MAO, Z.M., YANG, G., WANG, C.G. (1983): Study on the Evolution Relation of Genus Calligonum from Xinjiang Based on Number of chromosome and anatomic characteristics assimilative shoot. Acta Phytotaxon. Sin., 21, 44-48.

MAO, Z.M., PAN, B.R. (1986): The Classification and Distribution of the Genus Calligonum L. in China. Acta Phytotaxon. Sin., 24, 98-107.

OGAWA, M., HANADA, A., YAMAUCHI, Y., KUWAHARA, A., KAMIYA, Y., YAMAGUCHI, S. (2003): Gibberellin Biosynthesis and Response During Arabidopsis Seed Germination. The Plant Cell, 15(7), 1591-1604.

PARK, I.H., REHMAN, S. (1999): Studies on Seed Dormancy: Seeds Maturation in Relation to Dormancy in Goldenrain-Tree (Koelreuteria paniculata Laxm.). Acta Horticulturae 504 (eds.) Liptay, A., C.S. Vavrina and G.E. Welbaum, Proceedings of the sixth Symposium.

POȘTA DANIELA SABINA, (2009): Arboricultură Ornamentală. Editura Agroprint, Timişoara.

POŞTA DANIELA SABINA, HERNEA CORNELIA. (2011): Reseach Concerning the Production of Planting Material Using Generative Propagation on Albizzia julibrissin. Durazz. Buletin of University of Agricutural science and Veterinary Medicine Cluj-Napoca, pp. 423-429.

REHMAN, S., PARK, I.H. (2000a): Effect of Pre-Treatments on Dormancy of Goldenrain-Tree (Koelreuteria paniculata Laxm.) Seeds. J. New Seeds, 2: 29-36.

REHMAN, S., PARK, I. H. (2000b). Effect of Scarification, GA and Chilling on the Germination of Goldenrain-Tree (Koelreuteria paniculata Laxm.) Seeds. Scientia Horticulturae, 85(4), 319-324. 
REHMAN, S., PARK, I. H. (2001): Effect of Pre-Treatments on Dormancy of Goldenrain-Tree (Koelreuteria paniculata Laxm.) Seeds. Journal of New Seeds, 2(4), 29-36.

REN, J., TAO, L. (2004): Effects of different pre-sowing seed treatments on germination of 10 Calligonum species. For. Ecol. Manage. 195: 291-300.

RUDOLF, P.O. (1974): Koelreuteria paniculata Laxm., Panicled Goldenrain Tree. In: Schopmeyer, C.S. and T. Coord (eds.), Seeds of Woody Plants in the United States, pp: 474-475. Agriculture Handbook, 450, USDA Forest Service, Washington DC.

TAO, L., REN, J., LIU, X.M. (2000): Study on the Waterabsorbing Model of Two Calligonum Species Seeds. J. Arid Land Resour. Environ. 14: 89-91.

TAO, L. (2000): Genetic Diversity and Systematical Taxonomy of Genus Calligonum L. PhD Thesis, Environment and Engineering Institute of Cold and Arid Regions, The Chinese Academy of Sciences, PR China, $281 \mathrm{p}$.

YU, Z., WANG, L.H. (1998): Causes of Seed Dormancy of Three Species of Calligonum. J. NW For. Coll. 1: 9-13.

ZHANG, H.N. (1992): A study on the Species Selection of Calligonum and Its Forestation in the Drift-Sand Area of Cele County. Arid Zone Res., 9, 8-12.

\section{SAŽETAK}

Uspjeh pošumljavanja (ekološka i biološka kompatibilnost, ekonomska opravdanost, itd.) zavisi od upotrebe sjemena poznatog porijekla ili kvalitetnih sadnica. U ovu svrhu, važno je utvrditi karakteristike sjemena i eliminisati dormantnost. Cilj ovog rada bio je utvrditi klijavost sjemena Calligonum polygonoides L. sakupljenog u Iğdıru i Koelreuteria paniculata Laxm. Sakupljenog u Trabzonu. Da bismo eliminisali dormantnost za sjeme Calligonum polygonoides, uključili smo 11 različitih pretretmana, uključujući kontrolu: hladna voda (1-2 dana), vrela voda (10-15 min), giberelinska kiselina $\left(\mathrm{GA}_{3} 1000 \mathrm{ppm}, \mathrm{GA}_{3} 3000 \mathrm{ppm}\right)$, sumporna kiselina $\left(\mathrm{H}_{2} \mathrm{SO}_{4}, 5-10\right.$ min), 5 min sa $\mathrm{H}_{2} \mathrm{SO}_{4}+20$ min sa GA $31000 \mathrm{ppm}$ i 10 min sa $\mathrm{H}_{2} \mathrm{SO}_{4}+20$ min sa GA $3000 \mathrm{ppm}$. Najveća klijavost, od 50\% ostvarena je u pre-tremanu sa sumpornom kiselinom (5 $\mathrm{min})$, dok je najmanji procenat klijavosti $(3,33 \%)$ bio u kontrolnom pretretmanu. U pre-tretmanu sa vrelom vodom nije bilo klijavosti. Za sjeme vrste Koelreuteria paniculata, u svrhu eliminisanja dormantnosti izvršili smo slijedeće pretretmane sa kontrolom, hladna voda (1 dan), vrela voda (10 min), GA $1000 \mathrm{ppm}, \mathrm{GA}_{3}$ 3000 ppm, $\mathrm{H}_{2} \mathrm{SO}_{4}$ 5-10 min, 5 min sa $\mathrm{H}_{2} \mathrm{SO}_{4}+20$ min sa $\mathrm{GA}_{3} 1000 \mathrm{ppm}$ i 10 min sa $\mathrm{H}_{2} \mathrm{SO}_{4}+20$ min sa GA 3000 ppm. U ovom slučaju, najniži procenat klijavosti $(73,33 \%)$ uočen je u pre-tretmanu sa $\mathrm{H}_{2} \mathrm{SO}_{4}(10 \mathrm{~min})$, dok je najveća klijavost od $93.33 \%$ zabilježena u pre-tretmanu sa 10 min u $\mathrm{H}_{2} \mathrm{SO}_{4}+20$ min sa $\mathrm{GA}_{3} 3000$ ppm i hladnoj vodi (1 dan).

Corresponding Author: Ali Bayraktar: Karadeniz Technical University, Faculty of Forestry, Department of Forest Engineering, 61080, Trabzon-Turkey. e-mail address: alibayraktar@ktu.edu.tr 